\title{
Malfeasance and the Foundations for Global Trade: The Structure of English Trade in the East Indies, 1601-1833 ${ }^{1}$
}

\author{
Emily Erikson \\ University of Massachusetts, Amherst \\ Peter Bearman \\ Columbia University
}

\begin{abstract}
Drawing on a remarkable data set compiled from ships' logs, journals, factory correspondence, ledgers, and reports that provide unusually precise information on each of the 4,572 voyages taken by English traders of the East India Company (hereafter EIC), we describe the EIC trade network over time, from 1601 to 1833. From structural images of voyages organized by shipping seasons, the authors map (over time and space) the emergence of dense, fully integrated, global trade networks to reveal globalization long before what is now called "globalization." The authors show that the integration of the world trade system under the aegis of the EIC was the unintended by-product of systematic individual malfeasance (private trading) on the part of ship captains seeking profit from internal Eastern trade.
\end{abstract}

\section{INTRODUCTION}

In the first years of the 17th century, a few intrepid sailors on small English ships crossed the Atlantic and Indian Oceans, haphazardly initiating trade wherever they found willing partners. Within 150 years, thousands of

\footnotetext{
${ }^{1}$ We thank Julia Adams, Henning Hillmann, Joseph Ligman, Paolo Parigi, Joel Podolny, Robert Sampson, Toby Stuart, Quentin van Doosselaere, Duncan Watts, Harrison White, Josh Whitford, Chris Winship and participants of the Historical Dynamics workshop and the anonymous reviewers at the $A J S$ for their helpful comments. Ivy Washington and Zachary Luck assisted with the data collection. Financial support from the Institute for Social and Economic Research and Policy at Columbia University is gratefully acknowledged. Direct correspondence to Emily Erikson, Department of Sociology, Thompson Hall, University of Massachusetts, Amherst, Massachusetts 01003. Email: erikson@soc.umass.edu or psb17@columbia.edu
}

(C) 2006 by The University of Chicago. All rights reserved. 0002-9602/2006/11201-0005\$10.00 
sailors on hundreds of English ships laden with bullion, silver, and manufactured goods from the West set out for distant ports in the East Indies to collect commodities brought to the coast and readied for exchange by English factors resident in the East. Yet rather than return to England as directed, many captains cycled throughout the East, purchasing and exchanging goods manufactured in one locale for those of another, thereby profiting from uneven terms of exchange. These private traders, free riding on company resources, were engaged in an illegitimate and formally censured entrepreneurial activity in pursuit of their own interests. By using institutional resources for private gain, these private traders laid the foundation for an integrated global market, ${ }^{2}$ transforming the nature of EastWest trade in a short period from a simple dyadic structure to vastly more complex multilateral networks of exchange, ultimately leading to the emergence of densely connected global markets.

This was neither the first nor the last wave of globalization. But it was the first time that Northern Europe and East Asia were directly linked such that events in one region had immediate and direct consequences for the other-satisfying the requirements of a strongly defined conceptualization of globalization. By stimulating commercial development around the world, expanding markets, and catalyzing the British industrial revolution, the transformation of overseas trade was a crucial step in the development of modern capitalism. In short, before the invention of steamships, the East India Company (EIC) laid down the commercial ties that served as a template for the modern world-trade system. By identifying the mechanisms behind the radical transformation of the structure of EIC trade networks this article focuses on how this template came to be.

Drawing on a remarkable data set compiled from ships' logs, journals, factory correspondence, ledgers, and reports that provide unusually precise information on each of the 4,572 voyages taken by English traders of the EIC, we describe the EIC trade network over time, from 1601 to 1833. Specifically, we induce a graphical representation of the complete set of port-to-port linkages (26,000+ arcs) for all 4,572 voyages undertaken by the EIC in order to represent the structure of the English-East Indies trading network for the 233 years spanning the EIC's existence as a commercial organization. From structural images of voyages organized by shipping seasons, we map (over time and space) the emergence of dense, fully integrated, global trade networks. To anticipate the main argument, we show that the integration of the world trade system under

${ }^{2}$ The phrase "international trade" is anachronistic. By global we simply mean something less cumbersome than inter-societal, if not worldwide. We use the term global trade as a shorthand expression for large-scale long-distance integrated trade systems. 
the aegis of the EIC-what we will refer to as the structure for globalization-was the unintended by-product of systematic individual malfeasance (private trading) on the part of ship captains seeking profit from internal Eastern trade. ${ }^{3}$

The EIC has been the focus of considerable scholarly attention as a consequence of its critical role in first seeding and then securing the expansion of the British Empire in the East (Dodwell 1920; Roberts 1938). Likewise, there has been a long tradition of research that has considered in some detail the impact of EIC administration on the colonial experience and post-colonial inheritance (Burke 1969; Marx 1969). Thus there exists a wealth of secondary materials documenting EIC financial structure, management, and organization, in addition to descriptions of the EIC's broad social, economic, and political impact in the East and in Britain. While we make use of these materials, they are not the focus of this article. Our concern is with the emergent structure of trade. To our knowledge, no previous studies have undertaken a systematic analysis of the structure of English trade networks in the East. By focusing on the EIC trade network we identify when and how a structure for globalization was put into place.

Distinct communities of historians have focused on British trade in the East. One group (following Braudel 1972) whose interests center on the interaction of groups across bodies of water have dealt extensively with British trade as part of a broader pattern of trade and economic development in the Indian Ocean. This group stresses the replication of existing trade patterns and endogenous commercial development in the East and attributes British success to local partnerships and sheer presence, conceived in terms of the basic demographic aspects of trade-ships, men, and ports (Arasaratnam 1995; Barendse 1998; Borsa 1990b; Das Gupta and Pearson 1999; Prakash 1994; Saxe 1979). We consider and largely reject this demographic argument as insufficient. Here we show that the emergence of a densely embedded and tightly coupled trade network in the East-under EIC control-played the critical role in shaping EIC commercial hegemony. This structure enabled the EIC to harness and increase information on prices, terms of trade, and commodities, facilitating coordination across poorly linked markets. Gains in communication

\footnotetext{
${ }^{3}$ At the risk of being didactic, it bears stating that if Eastern trade was private trade for everyone-i.e., individual entrepreneurial activity-integration into a world market would not have arisen in this historical period. Private trading operated within the structure of existing EIC trade networks, interweaving otherwise largely disjoint markets. By analogy, spiders make webs between trees. Without the trees, the web would not hold up. The spiders are the private traders. The webs they spun are the trade routes they took. The trees are the institutionally sanctioned trade networks of the EIC.
} 
were coupled by increasing capacity to build redundancy of supply, thereby insulating the EIC from stochastic market fluctuations. Equally important, these emergent network structures provided the social foundations for sustained trade, thereby enhancing already-established networks of eastern trade, through local partnerships already noted above.

A second group of economic historians and organizational scholars has focused attention on the considerable innovation within the EIC with respect to financial management and organizational structure, thereby arguing that British hegemony in the East was the result of effective EIC strategy (Anderson, McCormick, and Tollison 1983; Chaudhuri 1965, 1978; Steensgaard 1981). These institutionalists rightly identify a set of London-based financial innovations, most importantly, the expansion of commercial instruments-for example, the joint-stock company and insurance systems - as critical elements in the establishment of British commercial hegemony (Carruthers 1996; North 1990). As with the principally demographic models, the basic insight is correct. Solutions to capitalization and risk dilemmas made it possible for ships to be in the East. It is also true that the crucial transformation of the structure of EnglishEast Indies trade, initially driven by company policy and orientation, persisted across striking changes in the company's fortunes, shifting patterns of European domination in the East, and sweeping changes in the Eastern political and social context. It follows that the structure of trade networks in the East was not determined by capital investment alone.

While there is partial truth to the institutionalist explanation that stresses the importance of internal instruments, developments, and directives for determining the course of English-East Indies trade, we show that the dynamics for change arose at the micro level. Critical in this regard were the private trade interests of ships' captains, whose pursuit of profit from exchange led to the emergence of complex trade structures well beyond those envisioned by the EIC directorate.

In this last context, historians have explored the impact of various private trading practices on European trade and specifically their role in strengthening the British presence in the East (Furber 1948; Marshall 1976, 1993; Watson 1980). A standard account of the creation of the British Raj is that resident English private traders pursuing private gain through tax evasion strategies drew the EIC and British government into local politics-from which they were unable to extricate themselves. This is the stuff of Kipling, as well as of Hobson and Lenin. Yet exactly how private traders provided a competitive edge to the EIC is less developed, beyond the idea that the English benefited, generally, from local partnerships forged by private traders within the context of specific ports (Saxe 1979; Kling 1979). This article specifies the role private traders played in shaping British hegemony in the East. Specifically, linking the 
microlevel activities of the private traders allows us to observe the development and elaboration of complex multilateral exchange circuits that give rise to densely integrated network components.

\section{Roadmap}

The organization of this article is relatively straightforward. We first describe the relevant historical background for understanding EIC trade policy and expansion in the East. In 1680, the company withdrew from the internal Eastern trade; by 1764 the EIC was positioned as the leading commercial force in the East, quickly thereafter emerging as a colonial power. The critical period-what we call the private trade period-for understanding the commercial development of a global market thus rests between 1680 and 1764. Much of this discussion focuses on the role of private traders whose activities integrated previously disjoint markets in the East. We consider the principal-agent problem and in this context briefly contrast the English trade structure with the Dutch trade structure. In order to disentangle structural features of the market from sheer scale increase, it is necessary to examine the constituent components of the English-East Indies trade- the basic demography of trade. We focus on the carrying capacity (ships and tonnage) of the EIC and the number of ports actively involved in the trade network. We then map the structure of the trade network over time. We show that by the middle of the 18th century, the EIC was in the position to control a densely connected and tightly coupled trade network. We identify private traders-EIC captains who took advantage of company resources for private gain. We then demonstrate that the fully integrated global trade network was the byproduct of private trading, thereby revealing how EIC management of Eastern trade created opportunities for malfeasance, and how, later, shifts in EIC policy constrained individual captains and provided the foundation for English colonial (vs. trade) domination.

\section{Historical Background}

A long history of trade linked the regions of Africa, Asia, Indonesia, and the Middle East before ships routinely rounded the Cape of Good Hope. Europe participated in this trade, but as a marginal figure at distant remove by both land and sea. Before the 16th century, trade routes to Europe from the East involved caravans across the deserts and plains. The prices of goods were significantly inflated to bear the expense of transportation, protection, and multiple transactions between merchants overseeing different portions of the route; consequently Eastern goods arrived only sporadically and at enormous cost. In 1488, the Portuguese 
discovered a safe passage around the Cape of Good Hope and began an overtly imperialist expansion into the East, conquering key ports in the Indian Ocean, notably Malacca, Macao, and Hormuz. While the Portuguese built up flourishing colonies, exacted concessions from merchants, and effectively excluded other Europeans from the area for a century, they had no significant impact on the existing patterns of trade, then dominated by Turks, Armenians, Javanese, Chinese, Bengalis, Arabs, Persians, and Gujaratis, in or across Europe and Asia (Barendse 1998; Braudel 1982, p. 447; Chaudhuri 1978; Steensgaard 1974). As the Portuguese increasingly concentrated on the Americas, other Europeans ventured past the Cape. The Dutch were the first Europeans to have a significant impact on Eastern trade; the British followed soon after. In 1600, the EIC was granted a royal charter of monopoly trade to the land east of the Cape of Good Hope and west of Cape Horn. Five years after the first Dutch penetration, the first English fleet set out in 1601. ${ }^{4}$ At its conception, the EIC was by far the largest and most ambitious merchant association yet conceived in England. By 1657, the EIC was a joint stock, M-form organization with permanent capital, regular stockholders' meetings, and a large administrative bureaucracy.

Getting to the East was only half the battle. Once past the cape, vast profits were possible, but the uncertain Eastern markets produced endemic fluctuations in return. We can distinguish three general periodsexploration (1600-1680), private trade (1681-1764), and consolidation (1765-1835). We focus on the second period in which the private trade of the captains flourished. Until 1680, the EIC struggled to establish effective communication, stable infrastructure, and routine supply chains. The impact of these persistent organizational weaknesses limited the EIC's capacity to respond to rapidly shifting market conditions (Basset 1960; Toussaint 1966). Consequently, what loomed large in England proved meager in the East. Throughout the 17th century, the EIC was

\footnotetext{
${ }^{4}$ Technically, this is the first incarnation of the EIC. The second incarnation resulted from a political and economic dispute over the monopoly rights of the company and the granting of seats on the General Committee, during which a second company was able to begin the process of establishing itself in the Indies. With leverage born of capital investment, exclusive knowledge, and squatters' rights, the original EIC was able to force the merger of the two firms. The United Company resulted from this merger. An excellent description of the events surrounding the merger in London appears in Carruthers (1996). Related events in the East, which mostly consisted of existing factors excluding the new company traders from markets, is described in numerous histories of the EIC (Keay 1991; Lawson 1993; Wilbur 1945; Williamson 1953). Since the result of the merger had more to do with dispersing profits of the company over a wider pool of London elite than reorganizing trading relations, we do not distinguish two separate companies, especially since the board of the first was carried over into the board of the second.
} 
a poor cousin to the Dutch East India Company (Vereenigde Oostindische Compagnie, or VOC), itself struggling to establish a place along side the empires and merchant networks in the East, across Central Asia, and into the Mediterranean (Adams 1994, 1996).

Following the Dutch, the EIC first tried to supplement their limited capital with profits derived from trade within the East. To this end, EIC ships were directed to piggyback on existing trade opportunities in the Indian Ocean, to participate in the "country trade." For example, cotton goods bought in Surat would be sold for profit in Batavia, providing extra funds for the purchase of pepper, then viewed as the most profitable commodity imported into England. Following this strategy throughout the 17th century, the EIC lagged after the Dutch in investment and profit (Adams 1996). More problematic, EIC involvement in the country trade led to continued market instabilities in England. Between 1667 and 1679, in an effort to routinize the home market and reduce exposure in the East, the EIC gradually withdrew from the country trade. By 1680 the EIC formally abandoned intraregional trading, which was left to individuals (Marshall 1993).

After 1680, when the EIC had withdrawn from the country trade, commercial opportunities within the East were numerous. Although the endogenous country trade in the East was significant and commercially sophisticated throughout the 17 th and 18 th centuries, it was fragmented into largely disjointed markets. This had not always been the case; Eastern trade systems were previously much more tightly integrated, and the penetration of Europeans contributed to a process of fragmentation already underway as a consequence of the decline of the Muslim Sultanates and the withdrawal of Chinese-sponsored foreign trade. By 1680, the Eastern trade system was dispersed and loosely jointed, split between markets serving China and those centered on the Indian subcontinent, further divided among isolated merchants loosely tied to geographic bases. ${ }^{5}$ For example, Gujaratis dominated the trade across India and Bugis operated in the Indonesia archipelago. Between 1681 and 1764, structural holes resulting from this regional clustering were bridged by English captains free riding on EIC resources in pursuit of private profit.

By the mid-18th century, the EIC was firmly established as the largest

\footnotetext{
${ }^{5}$ These structural features are recorded under various names, e.g., "systems" (Lombard 1981, p. 181), "networks" (Marshall 1993, p. 294), "commercial regions" (Chaudhuri 1978, p. 193), "worlds" (Braudel 1982, p. 533), "a network of interconnected systems" (Arasaratnam 1995, p. 15), "interlocking circuits" (Barendse 1998, p. 5), and adjectives, e.g., "dispersed," "loosely jointed" (Das Gupta 1999, p. 42), "multipolar" (Borsa 1990a), and "segmented" (Prakash 1997, p. xvi). Within communities, organization was typically limited to solitary enterprise or limited contractual partnerships such as respondentia and commenda (Das Gupta 1999, p. 129; Arasaratnam 1995).
} 
commercial interest in the East. Eventually, two different dynamics would snuff out the illegitimate private trade of captains. First, following the 1757 Battle of Plassey, at which the English defeated the Mughal Army, the EIC began to lay the foundations for their colonial empire. Consequently within a decade, the company had enhanced access to vastly increased resources operating within a new institutional structure and was thus capable of exerting effective control over its now robust trade network, thereby stamping out opportunity for captains. Second, free riding became simultaneously less lucrative. As the EIC monopoly weakened, the East was increasingly flooded with other actors. ${ }^{6}$ Captains free riding on EIC resources no longer held a distinct competitive advantage. The critical period therefore, rests between 1681 and 1764, a time when a fully integrated trade network emerged. And in this period, the critical actors were private traders.

Principals, Agents, and Private Trade

In theory, directors of the EIC sent ships to factories (warehouses where goods were stockpiled over the trading season) operated by merchants known as "factors," who managed the company trade through local brokers. Ships delivered the capital necessary for trade, and once loaded with goods they were dispatched to England. These simple operations in the East were spatially and temporally distant from England, often 6,000 miles-effectively six to eight months-from any central authority. Thus years would pass before the possible implementation of punitive measures in response to reported agent malfeasance. Likewise, market information was severely delayed before reaching London. Employees were the main conduits of this information, leading to pronounced information asymmetries. Market uncertainty and information asymmetry meant that the EIC could not easily evaluate underperformance or identify self-interested action. ${ }^{7}$ Consequently, EIC employees, captains and factors-once in the East - were necessarily operating with relative autonomy. This relative autonomy meant that principals' control over agents was difficult to resolve.

\footnotetext{
${ }^{6}$ The loss of EIC monopoly control over trade in the East following colonialization always seems counterintuitive at first. In England, free market agitators (Smith and Burke, e.g.) became more powerful, and the company-now a colonial power-came under greater public scrutiny. Erosion of monopoly control followed shortly.

${ }^{7}$ Compounding the problem was the fact that ship officers carried market information prepared by factors to the EIC directorate. The close quarters of officers over long periods of time were likely associated with enhanced capacity to collude. Similar dynamics underlying agent opportunism are identified by Kiser (1994; Kiser and Tong 1992).
} 
In the absence of control, rational agents pursue their own private interests, most often free riding off of collective resources provided by principals. The form this free riding typically assumed within the EIC was private trading, which was pervasive in all European companies operating in the East and was considered a significant threat to both the internal operations and the viability of the various national monopolies. ${ }^{8}$ The private trade had three illegitimate aspects—corruption, smuggling, and free riding. We consider each in turn. Corrupt factors frequently abused local privileges by engaging in private trade under terms of taxation granted to the corporate body. They competed directly with EIC trade, "borrowed" company funds to float trading ventures, and devised various methods of embezzlement. Officers and crew, allotted limited amounts of cargo space for their own personal intercontinental trade, often illegally supplemented their allotment in order to smuggle additional goods into England. Smuggling and corruption are best seen as opportunistic trimming, reducing company profit but not seriously affecting the dynamics of trade (Jones and Ville 1996a; Carlos and Nicholas 1996). Neither corruption nor smuggling challenged the capacity of the EIC to direct the acquisition of Eastern goods.

In contrast, when captains and officers actively engaged in the country trade in order to garner profit for themselves at company expense, the system by which the EIC procured goods was significantly distorted. This is the trade we consider in this article, simply because with respect to the organization of Eastern trade networks, the private trade of captains was by far the most important. ${ }^{9}$

The EIC directorate recognized that classical solutions to the principalagent problem-partnering within kinship groups, coalition formation, ransoming close relations-were not easily adaptable to the increased scale and span of control of their activities in the East (Van Dooseleare 2004; Greif 1994; Lovejoy and Richardson 1999). Likewise, early EIC solutions to the principal-agent problem-oaths and bonds-failed to induce employee compliance in the face of short-term contracts, an experience subsequently repeated by the Royal African and Hudson Bay companies

${ }^{8}$ As Jones and Ville (1996a) note, company histories for the EIC, Hudson Bay, Royal African, and Dutch VOC, among others "provide abundant evidence of persistent opportunism" and sustained, but largely unsuccessful, attempts to counter agent abuse of autonomy.

${ }^{9}$ Factors' participation in Eastern trade has been the subject of much attention. But, this participation followed existing trade routes, replicating already-established networks. The private trade of captains operated across the gaps in the existing local trade. The activities of factors were important for the subsequent establishment of British colonial rule, a topic beyond the scope of this article. 
(Carlos 1992). ${ }^{10}$ The persistent lack of resources and competition with the VOC led the EIC to adopt cost-cutting measures-abandoning the intraAsian trade, abandoning surveillance of employees, leasing ships, and insufficiently supplying factors with bullion. Part and parcel of this retrenchment was the adoption of a strategy of employee appeasement as a solution to the principal-agent problem (Chaudhuri 1978). ${ }^{11}$

One central element of the appeasement strategy adopted by the EIC shaped the densely embedded and tightly coupled trade network in the East we observe here. Officers and seamen were allotted sizable portions of the cargo hold for private goods when traveling between East Indian ports. This created an accidental, or perverse, incentive for captains to deviate from official voyages and prolong their stay in the East in order to gain from their private investment in the country trade (Anderson et al. 1983). Ultimately, failed EIC solutions to the principal-agent problem induced the macrostructure we observe.

In contrast, the Dutch approach to the principal-agent problem created long-term difficulties for the VOC, which early on used the country trade to supplement and supply capital for the continental trade. This is the strategy that the English mimicked (unsuccessfully) until 1680. The Dutch, like the English, confronted classic principal-agent problems. In contrast to the English, the Dutch were not willing to implement appeasement strategies that cut into their profits-for example, allowing individuals to participate in the country trade. Instead they attempted to increase their control over agents by establishing a single headquarter in the East (Batavia). Over time, this centralized organizational structure, or hub and spoke network, led to the stagnation of the trade, as Batavian authorities focused on existing rents and therefore failed to take advantage of new markets-the most prominent example being the failure to pursue direct trade with China (Adams 1996). Perhaps as problematic, Batavia's emergence as a center of consumption (and corruption) increasingly limited Dutch capacity to exploit the amplification of the eastern trade that the larger European market provided. In the long run, the Dutch lost footing in the East relative to the British because centralized local control in

\footnotetext{
${ }^{10}$ The English were not alone in failing to control agent activities. Adams, e.g., documents the breakdown of the Dutch company's control measures as a consequence of the EIC's multiplication of remittance paths available to employees in the East (1996).

${ }^{11}$ These concessions have been considered by both contemporaries and economic historians a reasonable if initially unintended solution to the difficulties of recruiting men to low-paid, life-threatening positions. EIC mortality rates fluctuated between $15 \%$ and 20\% per sailing season (Bruijn and Gaastra 1993).
} 
Batavia led to a siphoning of profits, blocked innovation and expansion, and a reduced capacity to respond flexibly to environmental uncertainty. ${ }^{12}$

Ironically, ex post, imperfect control over captains and ships led to longterm gains for the English company. Against this background, we consider the possibility that either EIC directors recognized potential gains from malfeasance and strategically implemented an incentive structure to encourage private traders, or having stumbled upon this arrangement, purposely failed to apply appropriate enforcement measures. Both are unlikely for two reasons.

First, the company records and correspondence are filled with exhortations for captains to proceed with "quick despatch" and "speedy passage" as well as with complaints about ships having missed the seasonal passage around the Cape of Good Hope. ${ }^{13}$ These complaints were motivated by the significant short-term losses to the company arising from delays that caused irregularity in the delivery of goods. In addition to problems of supply, the EIC leased their ships and paid demurrage fees for delayed voyages. Costs associated with demurrage likely accounted for up to $36 \%$ of the total profits within sailing seasons (Chaudhuri 1993). Second, the EIC regularly attempted to bypass contractual limits to their control by offering gratuities to timely captains and were only able to fully reform the process by which captaincies were bought and sold, thereby correcting the adverse selection problem, in the 1780 s-that is, after the private trading period (Anderson et al. 1983; Cotton 1949). ${ }^{14}$

Throughout the period from 1660 to 1780, the EIC directors perceived the purposeful delay of voyages as malfeasance and aggressively sought to curb these activities, succeeding only when the environmental and contractual obstacles to the exercise of their authority were overcome in the late 18th century. Captains also understood private trade to be malfeasant. For example, in writing about his experiences on the Delight in 1682, first mate Edward Barlow (subsequently a private trader and captain of the Liampo, lost off the cost of Mozambique) wrote, "[The EIC required an oath] obliging us not to buy and sell commodities which they transported or kept for their own trade, which end was all that anything could be got by, in tending to gain all themselves and none to their

${ }^{12}$ The classic instance is described by Phillip Selznick (1949), TVA and the Grass Roots: A Study in the Sociology of Formal Organization. Here, local control distorted the national project by subverting aims to those of the local political elite.

${ }^{13}$ An example can be found in "Instructions to Captain Brown, Commander of the Benjamin," internal correspondence, East India Company, 1689, British Library. See also Chaudhuri (1978).

${ }^{14}$ Initially, ship owners of vessels leased by the EIC retained the right to sell the captaincy as a transferable and inheritable good, thus severely limiting EIC capacity to enforce regulations. 
servants. And our oaths were not sufficient but we must give in bond a thousand of five hundred pound the piece for our true performance of the same, but how all people have kept their oath in that matter, let their own consciences be the judge" (Barlow 1934).

While always attractive to imagine that successful strategies that emerge ex post were perceived ex ante, the evidence in this case strongly suggests otherwise. EIC directors may have been ahead of their time, but they were not prescient. Of course, it is also the case that the interesting question, and the one we pose here, is not whether the EIC intentionally or unintentionally induced the network structure we observe but rather how variability of control within the EIC altered this structure.

\section{Free Riding, Self-Interest, and Connected Markets}

It is generally thought that when employees exploit access to company resources and deploy these resources for their own benefit-free riding on collective goods-negative outcomes result..$^{15}$ Beginning with Adam Smith, critics of monopolies have argued that the monopoly form nurtures corruption and rent-seeking behavior. For example, in 1776, Smith noted the collective cost carried by the English arising from "the extraordinary waste which the fraud and abuse, inseparable from the management of the affairs of [the EIC], must necessarily have occasioned" (Smith [1776] 1999, p. 215) ${ }^{16}$ This work precipitated a discussion that has dominated British political economy and economics for generations, pitting free trade advocates against supporters of monopoly rights (for history of the debate see Barber 1975; for recent instantiations, Carlos and Nicholas 1996; Jones and Ville $1996 a$ 1996b). This article suggests that the dichotomy may be false.

Following Smith, in this article, markets are composed of self-interested actors allowed to act in their own interest. In the East India case considered here, self-interested actors pursing private gain within a corporate framework, engaging in fraud and abuse, produced a connected market with benefits for all participants. Malfeasant captains built on and elaborated the stable infrastructure of the EIC, bridging the regional clusters that the EIC had earlier reproduced through participation in the country

\footnotetext{
${ }^{15}$ There are some notable exceptions-researchers who explicitly address variation in outcomes across different configurations of principle-agent relations. These include Perrow (1986), White (1985), and Shleifer and Vishny (1993), among others.

${ }^{16}$ Smith was referring to territorially based employees extracting extortionate land taxes from the Indian countryside; however, the argument became an important component of a larger argument against the monopoly as a commercial form.
} 
trade. The unintended consequences of the EIC's loss of control created the characteristic features of capitalism: well-connected buyers and sellers.

Similar dynamics are found elsewhere. The finding that informal ties are crucial to the process of stabilizing trade networks and integrating markets supports historical work on the premodern organization of longdistance trade, specifically, the construction of interlocking substructures facilitating the growth of capitalism (Braudel 1972 1974; Granovetter 1985). Likewise, a number of works have emphasized strong ties and redundant contacts (networks, coalitions, guilds, prestation chains, and multidivisional firms) as solutions to distance-based agency problems (Anderson et al. 1983; Curtin 1994; Greif 1989; Grofman and Landa 1983; Hage and Harary 1991). These works identify why cohesion and redundancy solve the extreme agency and trust problems posed by long-distance trade, exacerbated in eras of slow transportation and communication.

Here we identify the dynamics underlying structural cohesion of an emergent global trade network in the East, tracing its production to a loss of control that multiplies external contacts, thereby securing steady supply streams and lowering prices through communication across markets. Central components of this argument include the possibility of persistent localism through bureaucratic processes (Bearman 1991; Savage, Stovel, and Bearman 2001) and the importance of organizational flexibility in uncertain environments (White et al. 2004; Piore and Sabel 1984; Weick 1976). Considered as such, the decentralization of EIC trade and organization into the hands of the private traders supports the observation that marginal actors generate essential innovations (Boorman and Levitt 1973; Burt 2004).

\section{DATA}

Data for this article arise from The Catalogue of the East India Company's Ships' Journals and Logs, 1600-1834 and The Biographical index of East India Company maritime service officers: 1600-1834, sources which integrate the journals, logs, ledgers, imprest books, pay books, receipt books, absence books, company papers, and voluminous correspondence of the company relevant for each ship and employed officer (see Farrington $1999 a, 1999 b)$. From the first volume, we have a complete list of the 1,480 ships (4,725 voyages) that were engaged in EIC trade from 1601 to 1835 . Eighty-five percent of the entries for voyages contain a complete set of ports visited with dates of arrival and departure. ${ }^{17}$ All ships list the trading

${ }^{17}$ Of the missing 724 voyages, 188 were terminated due to rotting, wreck, acts of aggression, and other misadventures; 117 voyages are missing port data for the period focused on here, from 1680 to 1764 . 
season in which they were active and 99\% include the intended destination. Less systematically, there is information on ship tonnage, dimensions, crew size ${ }^{18}$ armaments, principal owners, and shipbuilders. In the analyses reported below, ports fall in and out of the network. We consider ports not visited within a four-year period inactive. Throughout, we follow convention and refer to a complete round trip by the term voyage, a journey to the destination port without returning as a passage; we reserve trip for the individual port-to-port hops that make up both passages and voyages. The level of detail included in the data set allows a day-to-day recreation of the location of ships (through reference to arrival and destination ports), which spans 85,838 days from the granting of the royal charter, December 31, 1600, to the return of the last ship, the General Palmer, on March 3, 1835. Throughout we analyze the structure of trade for four-year periods determined by the departure date of each voyage. This allows us to identify structural change over time while retaining a sufficient number of ties connecting ports so that we may reliably measure structural properties. ${ }^{19}$ This means that a ship that began its voyage in 1701 and continued to travel until 1705 is included in the 1700 observation period only. Data on ships and voyages is complemented by detailed career histories for all $(12,000)$ EIC crew on ships who attained the rank of sixth mate or above. For all officers, we retain data on prior voyages. For each voyage, we use these data to build a complete crew list. We use this information to construct a measure for regional experience.

\section{The "Demographic" Picture}

We start with the simple demographics of the East Indian trade, conceived as the descriptions of the fundamental units of trade, ships, and ports. These indicators reflect development of the company over time as typically described by historians. The unsteadiness of the period leading up to 1680 transforms into steady growth during the period of greatest company prosperity, from 1680 to 1760 , leading into the rapid increase in investment after 1770 and the beginning of colonial entrenchment. Here we focus on

\footnotetext{
${ }^{18}$ Both crew size and tonnage were systematically underreported. Since the EIC had to pay additional fees when crew sizes exceeded 100, the modal crew size reported is 99 , even when this number is absurd with regard to the necessities of running a ship. The absurdity is obscured in voyages where the EIC reported a tonnage of 499 in order to avoid a decree requiring the presence of a chaplain on board ships over 500 tons (Cotton 1949).

${ }^{19}$ Individual voyages yield networks too sparse for analysis, and partitions across time yield calendrical cross-sections that split voyages. Comparable analyses for two-year windows (available from the authors on request) show similar results to those reported here.
} 
the number of ships setting out to sea, average tonnage, and the number of active ports over the whole period from 1600 to 1833 .

Results are reported in figure 1, for four-year periods. Figure 1 provides strong evidence of increasing intensity of contact, peaking with respect to number of ships in the late 18th century. This peak occurs after the EIC establishes commercial control over the East-having outcompeted the VOC. The timing shows that expansion, in this case sheer number of ships, cannot account for EIC success in the East, thereby ruling out the standard demographic explanations. Over the same period, ship size increased almost continuously. At the turn of the 19th century, the typical boat was two to three times larger, in terms of carrying capacity, than the boats of the early 17 th century. Subsequent declines in numbers of ships are mirrored by significant increases in average tonnage. The number of active ports jumps sharply in 1680 and remains at high levels through the middle of the 18th century; declining sharply thereafter. After 1760 , more ships went to fewer ports as the EIC exerted more control over the activities of captains. The period between 1680 and 1760-when private trade was at its peak-thus appears as the critical period for the EIC expansion into the East and solidification of trade there. Throughout, the company's largest exports were gold and silver bullion. Imports consisted mainly of pepper, cotton goods, silk wares, tea, coffee, chinaware, and opium. ${ }^{20}$

\section{ANALYSIS}

We used the data described above to convert ships' routes into networks over time to reflect the passage of ships from port to port. In all of our figures, nodes represent ports visited and arcs represent (schematically) ships' routes: adjacent nodes are linked by trips. Arrows indicate the direction of travel. This process yields a graph of equally weighted ties directed according to the path of the ship that can be split into any number of horizontal cross-sections. As noted earlier, we aggregate these data into 58 four-year seasons determined by the opening date of a voyage.

Figure 2 illustrates how we compose a network, using as an example the voyages of three ships that sailed in the 1720 season, the Prince Augustus, the Lyell, and the Princess Amelia. A quick glance at each panel reveals that ports (indexed as small circles) are displayed according to latitude and longitude. The Indian subcontinent is visible in panel A. In

${ }^{20}$ These commodities were traded alongside a bewildering variety of goods, enumerated in lists lasting many pages. A short sample might include diamonds, rubies, rose attar, shiraz, dragonsblood, cardamom, lac (an insect by-product), galls (little homes made on oak trees by insects), rose maloes, sal amonniac, assafoetida, bezoar, and brimstone. 


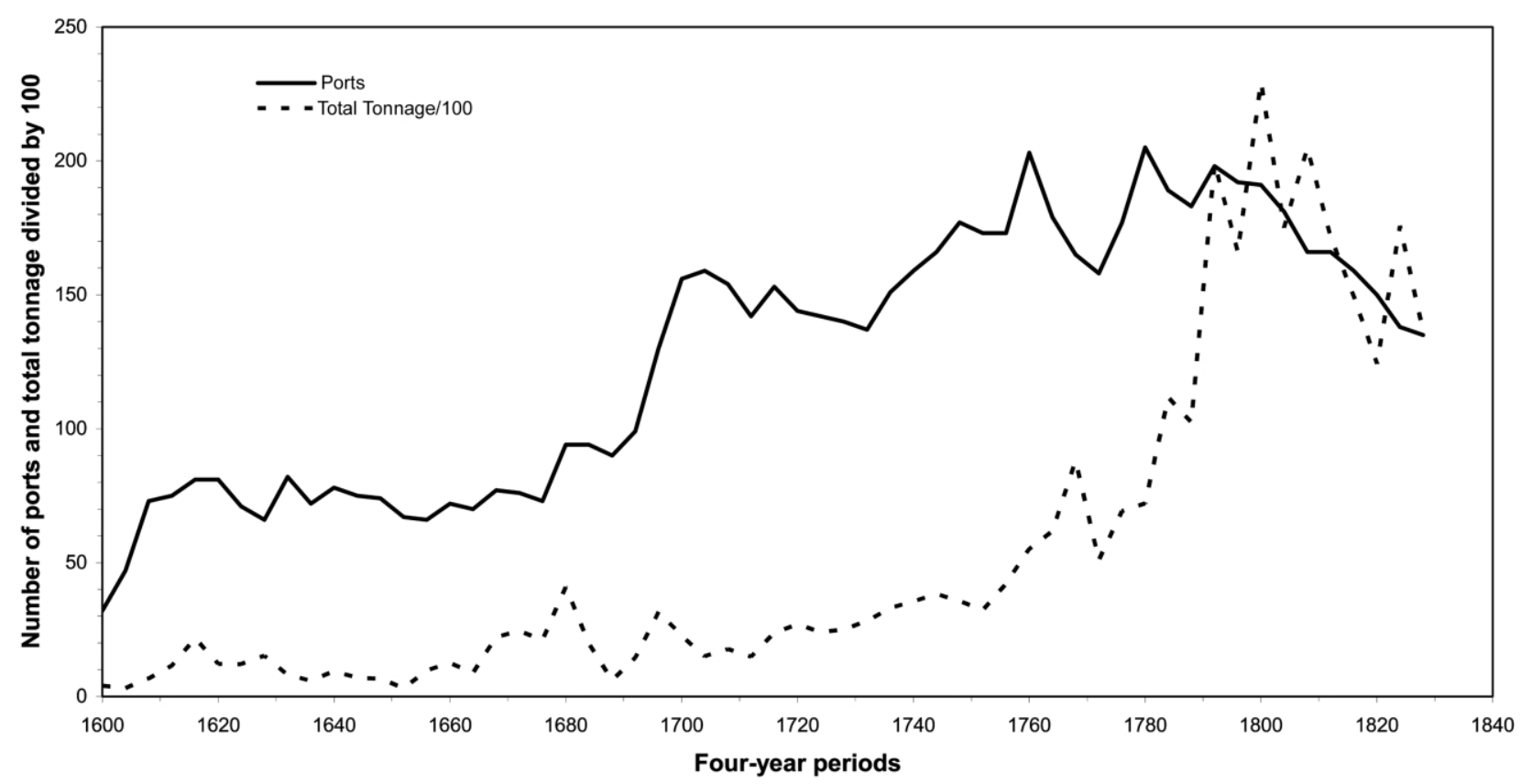

FIG. 1.-Ports and scaled total tonnage over four-year periods 


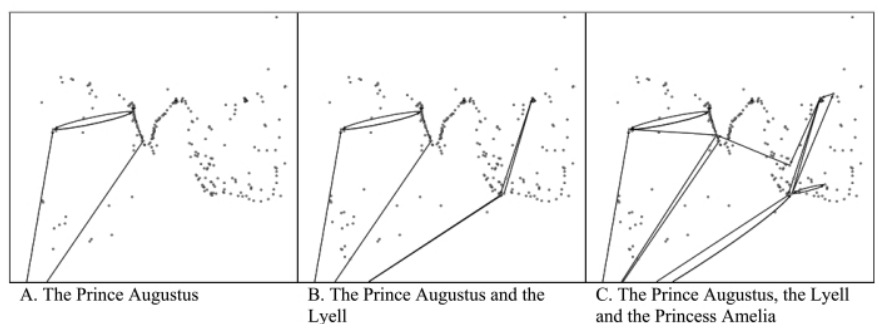

FIG. 2.-Spatial representations of the voyage of the Prince Augustus (panel A), the voyages of the Prince Augustus and the Lyell (panel B), and the voyages of the Prince Augustus, the Lyell, and the Princess Amelia(panel C), 1720.

the upper-left corner are mideast ports. In panel B, the Indonesian archipelago to the south (bottom right) and China (top right) are visible. Lines linking ports schematically represent the boats' voyages.

Panel A charts the travels of the Prince Augustus which departed England November 25, 1722, arrived in Mokha on June 3, 1723, cycled between Mokha and Bombay, headed for Surat, proceeded down the Malabar coast to Cochin, and returned to England. Panel B includes the voyage of Lyell, which sailed directly to Batavia (now Jakarta), went to Whampoa (now Guangzhou), returned to Indonesia, and proceeded home. In panel $\mathrm{C}$, we include the Princess Amelia, which cycled back and forth between ports, visiting Banjarmassin, Batavia, Mokha, Bombay, Tellicherry, Amoy, Whampoa, and Malacca, crossing paths with both the Prince Augustus and the Lyell, thereby linking the disparate market clusters of the East into one large component. For each trading season, we induce graphs of linked ports by pooling voyages sent out under the auspices of the EIC. The resulting graphs provide snapshots of the structure of trade for each period. In what follows, we analyze the structure of these graphs, to provide insight into the dynamics of change.

\section{Structure over Time}

The transformation of the structure of the EIC network is shown in figure 3 , which reports the complete network for five trading seasons (1620, $1660,1720,1760,1796,1820)$; that is, the entire period of EIC engagement in the East. As before, ports are circles located with respect to latitude and longitude, voyages are represented as lines. ${ }^{21}$

As shown in panel A, by 1620 the company was heavily involved in

${ }^{21}$ Across each panel, some lines appear darker and thicker than others. Here lines are not weighted by number of voyages; line thickness and dark regions of the graph indicate densely proximate routes. 

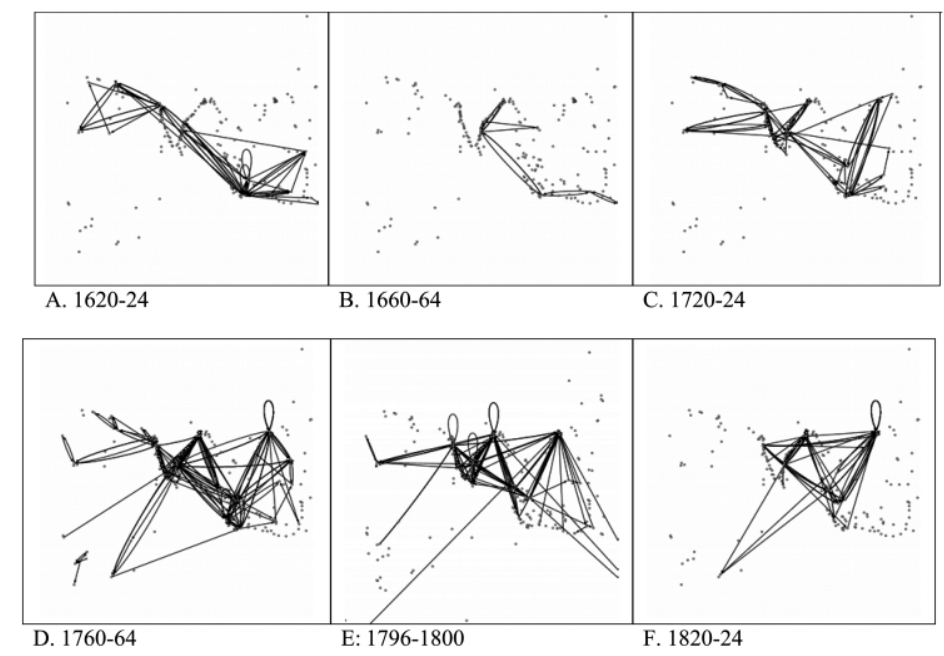

FIG. 3.-Development of Eastern trade over geographic regions in snapshots of six four-year periods 
the country trade. The cohesive network linking Indian, Indonesian, and Middle Eastern ports reflects this engagement. As is also evident, direct trade with China was not yet established. By 1660 (panel B) the EIC was facing severe financial difficulties exacerbated by political turmoil in England and aggressive business tactics of the more powerful VOC. Against this background, the EIC withdrew from the country trade; consequently their footprint in the East was significantly reduced. Substantial growth and expansion was evident by 1720 (panel C): integration increased and the geographic reach of the network had expanded to the Persian Gulf, up through Indonesia, and into the Far East markets of Malaysia and China. Behind this radical transformation lay intense engagement of private traders with the country trade. By 1760 (panel D), at the end of the private trade period, the EIC trade network had fully integrated the previously separated trading regions of the East, linking the Red Sea, Persian Gulf, West India, Bengal, Ceylon, Indonesia, Malaysia, Philippines, and China through numerous redundant paths across ports. EIC central consolidation and control are evident by 1796 (panel E). By 1820 (panel F), the number of paths and regions were drastically reduced as the EIC's trade became focused on major ports within the territorial domain of the British.

\section{Microlevel Processes}

We now turn to understanding the dynamics associated with the radical expansion and solidification of the EIC trade network in the period from 1680 to 1760 , again revealed in figure 3 . In this period, the EIC acquired a dominant position in both local and overseas trade and thereby transformed the structure of the global trade networks in which East-West trade was organized. Here we show that the emergence of a dense, fully integrated, global trade network rested on the illegitimate behavior of captains seeking to profit from private trade.

The first difficulty lies in identifying private trade voyages. Captains engaged in the illegitimate diversion of EIC resources for private profit did not document their malfeasance for company records. ${ }^{22}$ Consequently, we use voyage characteristics to identify private trading. The trace of private trade is revealed by the intersection of voyage duration and $c y$ cling. As noted above, private trade was illegitimate when captains diverted corporate goods from the EIC's intended ends. Thus, free riding could only occur when captains "deliberately 'lost the season' for their return voyages to Europe by moving in a dilatory fashion from Bombay

\footnotetext{
${ }^{22}$ Historians, e.g., have not found confessional annotations in company books documenting engagement in private trade. Nor have we.
} 
to other Asiatic ports, investing and reinvesting their 'privilege,", ${ }^{23}$ (Fitzgerald 1777; Furber 1948, p. 280; 1976, p. 195; Watson 1980, p. 71; Anderson et al. 1983, p. 478). Ships were expected to stay in the East for six months. Here, presumptive free traders are on voyages whose duration exceeded average duration for each sailing season, measured from time of arrival at the first port in the East Indies to time of arrival at the last port in the East Indies. ${ }^{24}$ Most of the ships identified as private traders stayed in the East for more than a year.

Private traders engaged in the country trade, buying goods in one port and selling them in others; thereby linking otherwise disjoint Eastern trade regions. In contrast, EIC directed voyages left England for ports where English factors waited with goods for return shipment. When boats went from one port to another in the East, they did so either to participate in the private country trade or to procure new goods for freight back to England. Because time was of the essence, captains engaged in legitimate EIC trade would not double back to previous ports, thereby inducing cycles within their voyage. The main purpose of cycling was trade, and the traders in the East-after the EIC pulled out of the country tradewere private traders. Consequently, voyages with cycles are conditionally considered private trade voyages, where a cycle is defined as a path that brings a voyage back to a port previously visited. ${ }^{25}$

Protocols varied across ports; each had its own set of officials, who required custom duties, gifts, and bribes with varying degrees of specificity and ceremony. Norms varied significantly across trading regions; experience on the Indian subcontinent was not easily transposed to Indonesia or China. Captains and crew engaged in EIC trade were able to rely on institutional knowledge to negotiate these complexities. Private traders shouldered greater risk and lacked the institutional safeguards in place for legitimate voyages. Consequently, private traders had to rely on their personal experience in order to pursue commercial opportunities. Since prior experience in the East was critical for negotiating private trades, it

\footnotetext{
${ }^{23}$ The privileges referred to here are the officer's allotment of cargo space on EIC vessels, described above.

${ }^{24}$ This measure avoids bias arising from a steady decrease in the duration of trips and variability due to fluctuations in the weather. The decrease in mean voyage duration over time was driven less by technical innovation than increased control of the EIC over trade routes (Menard 1991; Steensgaard 1965).

${ }^{25}$ The EIC did however occasionally let out the ships for local freight voyages. For example, in 1702, the Colchester was leased to an Armenian merchant (Sarhad Israeli) to take goods to Balasore and Bandar Abbas from Madras; sometime later the Hesterwas leased (by Janardhan Seth, a Hindu merchant) for a similar freighting voyage (Prakash 1994). To avoid including such trips, we exclude voyages containing only cycles of length 2 -that is, cycles involving only two ports, e.g., $\mathrm{A} \leftrightarrow \mathrm{B}$. Neither the Hester not the Colchester, e.g., are coded as private voyages.
} 
follows that captains engaged in the private trade ought to have had more experience specific to the destinations of their current voyage than captains pursuing legitimate trade. We assess our indicator of private trade-voyages characterized by cycling and extended duration-by generating an experience measure for captains, specific to each voyage undertaken. Presumptive private traders ought to have had wider prior experience. Table 1 reports the association between experience and private trading, reporting a count of the number of distinct regions previously encountered by a captain, for each target voyage, for all voyages that set out from England between 1680 and 1760 - the period where private trade was possible.

The results of table 1 show that captains of private trade voyages are more likely to have had greater levels of regional experience tailored to their current voyage. Note that inexperience in the East is strongly associated with extended duration. Captains without experience were much more likely to miss sailing seasons than those whose previous tenure in the East was substantial. Thus, this assessment is conservative-the strong association between private trading and experience, for those with experience, is striking, offering construct validity for the private trade indicator. ${ }^{26}$ Consequently, in subsequent analyses private trade voyages are those characterized by cycling and excessive duration.

The Impact of Private Traders on the Structure of Trade in the East

We now consider the effect of private traders on the macrostructure of British trade in the East. Our strategy is simple. We assess the impact of the private trading voyages on the macrostructure by removing these voyages from the network. This returns a new graph of the overall structure, which we refer to as the private trade removed graph. This graph is the graph of the network without private traders. Naturally, by re-

${ }^{26}$ The test is conservative because we assume that inexperienced captains are more likely to make errors that lead to disaster at sea. This assumption is borne out by the data. The following tabulation shows that inexperienced captains, those with fewer than two previous voyages with the EIC have significantly higher odds of experiencing an accident (Pearson $\chi^{2}(1)=27.1046 ; P=0.000$; disasters include abandoning ship, wrecks, fires, captured by enemy forces, lost at sea, engaged by pirates, and mutiny; numbers in parentheses are odds ratios).

\begin{tabular}{cccr}
\hline \hline CAPTAIN's & \multicolumn{3}{c}{ Voyage Outcomes } \\
\cline { 2 - 4 } ExPERIENCE & No Disaster & Disaster & Total \\
\hline 0-1 prior voyages $\ldots$ & $1,003(.97)$ & $85(1.60)$ & 1,088 \\
$2+$ prior voyages $\ldots$. & $3,138(1.01)$ & $127(.80)$ & 3,265 \\
Total .......... & 4,141 & 212 & 4,353 \\
\hline
\end{tabular}


American Journal of Sociology

TABLE 1

Cross Tabulation of Private Trade Voyages and Legitimate Voyages over the Regional Experience of Captains, Specific to Target Voyage, $1680-1764$

\begin{tabular}{|c|c|c|c|}
\hline Experience & Legitimate Trade & Private Trade & Total \\
\hline & 224 & 79 & \\
\hline \multirow[t]{2}{*}{$0 \ldots \ldots \ldots \ldots$} & $(1.01)$ & $(.97)$ & 303 \\
\hline & 301 & 66 & \\
\hline \multirow[t]{2}{*}{1} & $(1.12)$ & $(.67)$ & 367 \\
\hline & 178 & 76 & \\
\hline \multirow[t]{2}{*}{2} & $(.96)$ & (1.11) & 254 \\
\hline & 65 & 40 & \\
\hline \multirow[t]{2}{*}{3} & $(.85)$ & $(1.42)$ & 105 \\
\hline & 14 & 27 & \\
\hline $4+\ldots \ldots \ldots \ldots$ & $(.47)$ & $(2.45)$ & 41 \\
\hline Total ... & 782 & 288 & 1,070 \\
\hline
\end{tabular}

moving directed arcs, we reduce the density of the original graph. Thus the differences between the private trade removed graphs and the complete graphs are possibly artifactual. To ensure that our results are not an artifact of arc deletion, we return to the original data structure, which included private traders and all other voyages. From the set of all other voyages, within each period, a voyage matched on destination for each private trade voyage is selected at random. We identify these as "matched voyages." We remove from the complete data set, within each four-year period, voyages matched to the private trade voyages. We label the resulting graph the matched voyages removed graph. Since we removed comparable voyages, we can directly assess impact of the private trade on the macrostructure without fear that differences are artifactual.

It is useful to conceptualize private trade characteristics as a treatment affecting network construction, allowing a comparison between the macro-level structure of networks subjected to treatment with the structure of a networks serving as a control set. For convenience, the private trade removed graphs - those lacking voyages with private traders-can be thought of as the control group. The graphs with matched voyages removed can be considered the treatment group. In this regard, the strategy mimics a classification tree approach to propensity matching (Stone et al. 1995). One can see the effect of private trade in the graph with matched voyages removed. Likewise, there can be no effect of the private traders on the graph with the private trade voyages removed. But it is more intuitive to think about the effect of private traders on the macrostructure by focusing on what happens to the structure when they are removed from the network. This is the approach we take. 
Figure 4 shows the macrostructure for the trade network at the start, middle, and end of the private trade period-1680, 1712, 1720, 1728, and 1760. Each panel allows comparison of the structure of the legitimate graph and illegitimate graph, revealing the impact of the private traders on the network. Here we position ports using a standard spring algorithm widely used and available in Pajek, in order to better reveal the structural comparison. ${ }^{27}$ For reference, the complete trade network for each period is also shown. Ignoring a single exploratory voyage to Madagascar in 1760 (indicated in panel $\mathrm{E}$ at the bottom left of the complete trade network for 1760), over the whole period, the complete network is a single interconnected component. Of interest then is the effect of private trade on the component for each period. Focusing first on 1680, at the start of the private trade period, it is evident that the matched voyage removed and private trade removed graphs are essentially similar. In marked contrast, the impact of private trading on the macrostructure is strongly evident in the middle of the period. The graphs for 1712, 1720, and 1728 show that, without private traders, the entire system of EIC trade in the East is decomposed into two disjoint components. By 1760, as the EIC reasserted control over the trading activities of captains, the effect of private trade is muted, but still visible. A single port connects two otherwise separate regions.

\section{Network Integration}

In figure 4, the absence of graph connectivity at the peak of private trading in the legitimate trade graphs is visually obvious. The key impact of private trading was to knit together otherwise disconnected regions. In order to capture the extent of network integration directly we must take into account both the number of discrete components and the proportion of ports within those components. To do this, we invert a standard measure of heterogeneity, specifically

$$
\text { Heterogeneity }=1-\sum_{i}^{n}\left[\left(a_{i} / z\right)^{2}\right]
$$

where $a$ represents the number of ports in component $i$, and $z$ represents the complete count of ports in the network (Finke and Stark 1988). To understand how this works, it is important to realize that a connectivity level of one means that all of the nodes (ports) are integrated into a single

\footnotetext{
${ }^{27}$ The partitions in the private trade removed graphs occur across regions; e.g., in 1712 the partition is between India and Indonesia, while in 1720 and 1728 the partition lies between the Western and Eastern Indian Ocean.
} 
American Journal of Sociology
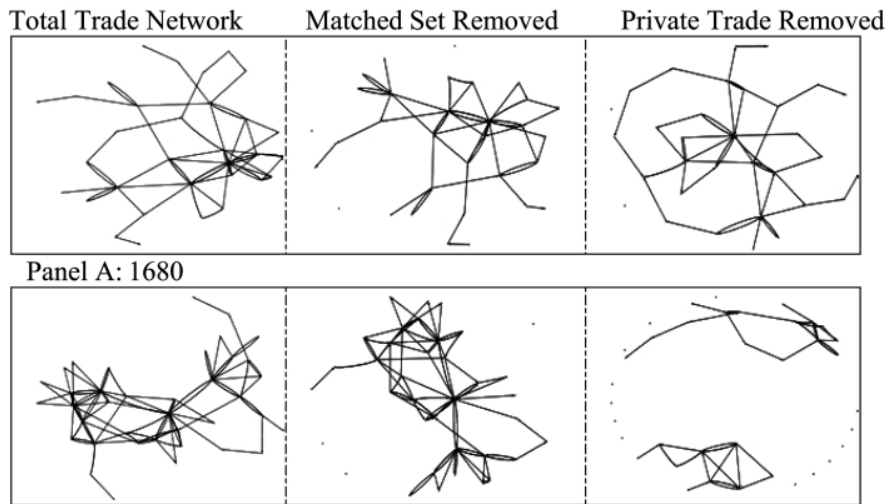

Panel B: 1712
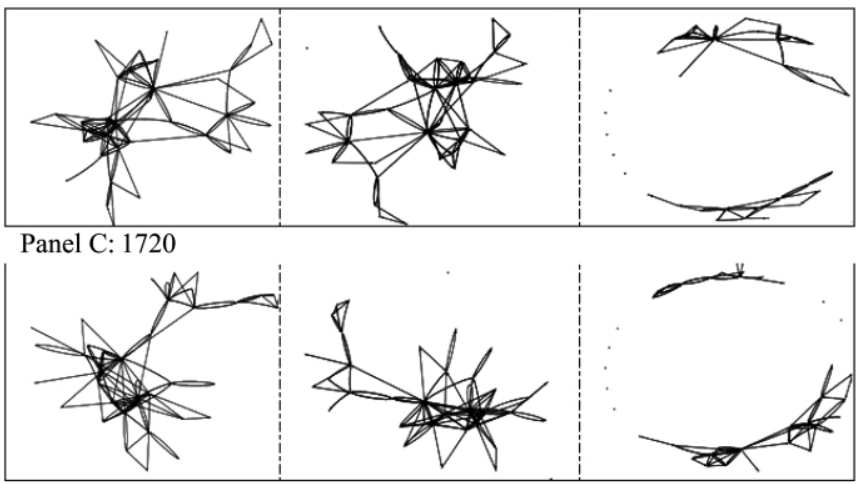

Panel D: 1728

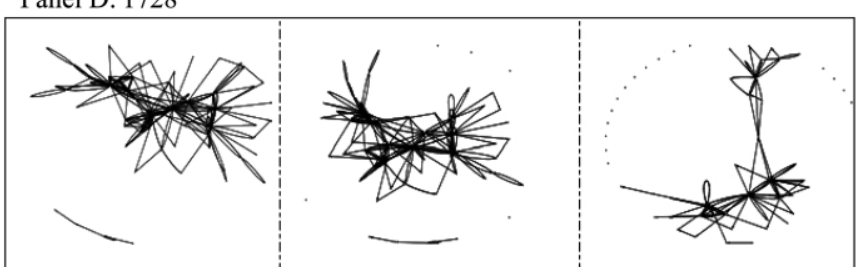

Panel E: 1760

FIG. 4.-Network visualizations of the EIC's Eastern trade

connected component; a connectivity level of two means that all nodes are integrated into a single connected bicomponent. We use

$$
H=\sum_{i}^{n}\left(a_{i} / z\right)^{2},
$$

so that an increase in integration pushes the measure closer to the next connectivity level, for example from fragmentation to a single component 
$(0 \rightarrow 1)$, or from a component to a bicomponent $(1 \rightarrow 2)$. Figure 5 reports integration scores for the complete network, for the graphs with private traders removed, and for the graphs with matched voyages removed.

Higher scores index greater integration. As is evident from figure 5, the total trade network from 1680 to 1760 is almost always a fully connected component. For the whole period, only in 1696 and 1764 does the graph break into two components-note that the integration score for the total networks dip below "1" for these years. For all other periods, the total network is a fully connected component with a densely integrated core yielding integration scores well above $1 .^{28}$ The key finding is that the graph with the matched voyages removed is always more densely integrated than the graph with the private traders removed. The snapshots shown in figure 4 visually indicate the role of the private traders in integrating the East Indian trade network. Figure 5 demonstrates that the visual impact is real-not an optic artifact. Private trading voyages' contribution to integration is significantly greater than the contribution of the matched voyages. Without private traders, the graphs fragment into large regional clusters dislocated from the main component

\section{Standard Network Indices}

The integrative effects of the private trade are also evident in standard measures of network structure, including graph density, size of the largest component, and size of the largest bicomponent. For each, observed measures for the private trade removed and matched voyages removed graphs are first subtracted from observations taken on the total network. We then calculate each measure as a percentage of the total network-that is, their impact. Relative impact, reported in figure 6 , is the ratio of private traders impact over other traders. Where values exceed one, private traders have greater relative impact on network structure than the matched voyages. This is the case for each variable at each moment in time.

Density is simply the number of trips between ports relative to the total possible trips between ports. Consequently, a measure of weighted density mainly captures the increase in the number of ships at sea. To avoid this, we calculate the density of the directed binary port-to-port network. Ships may set out from one port and return-in cases of bad weather or other similarly unpredictable events. We do not include these loops in the measure of density since self-ties have no substantive meaning in this context.

\footnotetext{
${ }^{28}$ If the total network registers at integration level 2, this would mean that every port would have at least two redundant pathways to every other port in the network-i.e., the graph would be a bicomponent. Here we observe extremely high scores characteristic of knotted and cyclic networks.
} 


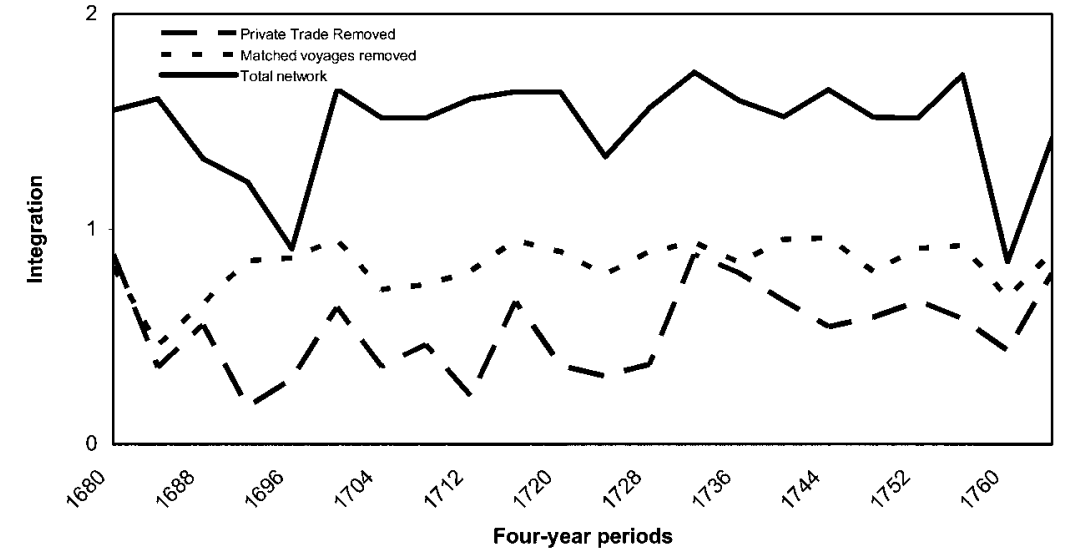

FIG. 5.-Integration levels of total graphs, graphs with private trade removed, and graphs with matched voyages removed over four-year periods from 1680 to 1764 . 


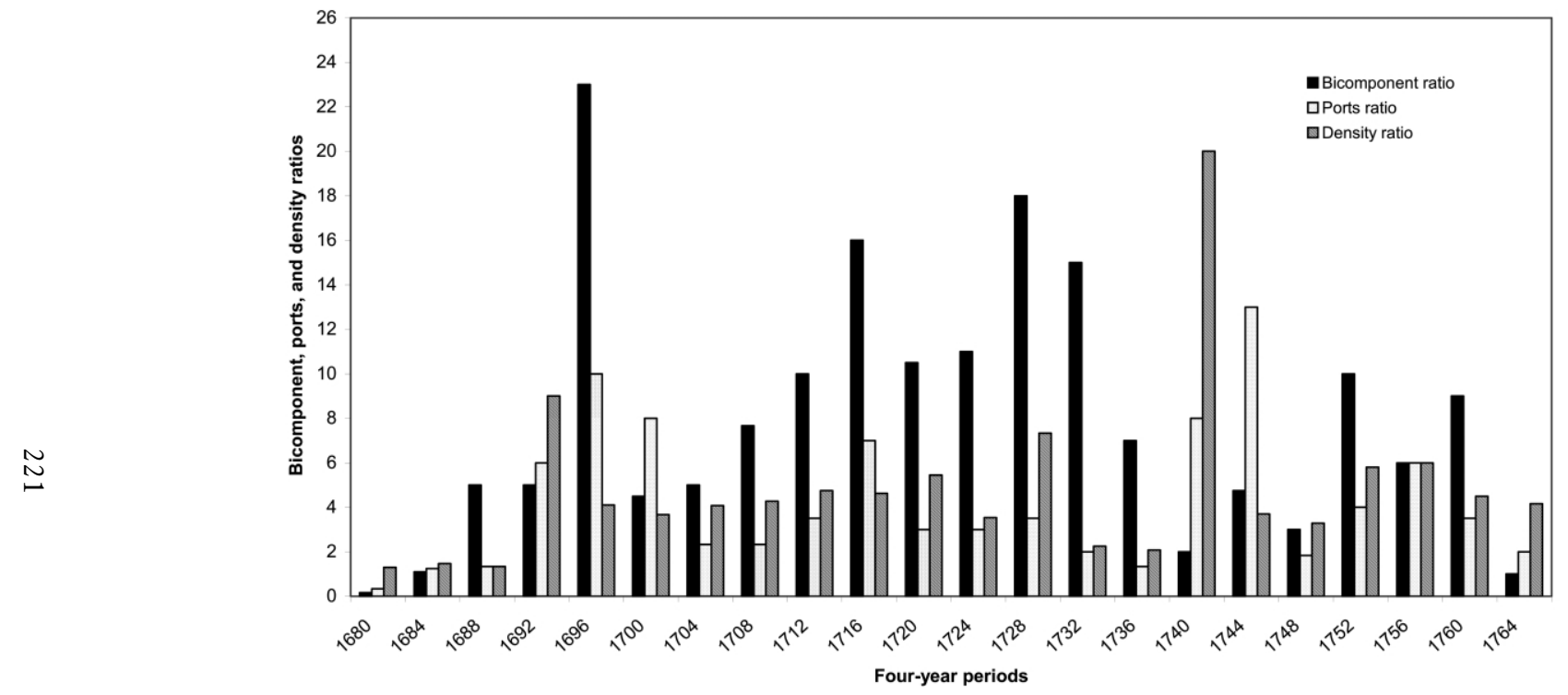

FIG. 6.-Relative impact of private trading on graph density, the number of ports in the trading network, and largest bicomponent size in the East, $1680-1764$. 
As is evident above, private trade typically accounts for more than five times the density accounted for by the legitimate voyages. This means that in addition to linking regions, the activity of private traders significantly enhanced within region contact, thereby building multiple robust channels for the transmission of information on prices, terms of trade, and available commodities.

In addition to building within-region network infrastructure and crossregion trade networks, private traders directly incorporated markets into the existing network. The impact of private traders on network size (sheer count of ports) is consistently strong. This suggests that the process of establishing and sustaining ties to numerous markets was an ongoing byproduct of the pursuit of the private trade. In fact, private traders are two times more likely than other captains to discover new ports, subsequently integrated into the English East Indian trade network.

Finally, figure 6 considers the impact of private trade on the number of ports embedded within the largest bicomponent. Recent work on large complex networks (Moody 2004; Moody and White 2003; White and Harary 2001) has shown that bicomponents provide the best measurement for assessing embeddedness and structural cohesion. In addition, networks that evidence structural redundancy — revealed through identification of graph bicomponents-are significantly less vulnerable to stochastic (or purposive) disruptions. This structural element is critical for market contexts in general since uninterrupted delivery of goods and information is central for efficient market clearing, and in the East (and premodern markets) especially so, given striking temporal and spatial discontinuities. In addition, the presence of bicomponents eliminates information asymmetries that often arise in hub and spoke networks-identified by Adams (1996) as one of the principle reasons for Dutch decline in the East.

\section{Network Simulation}

We now consider results from simulation. In the previous section, voyages matched by destination and period serve as a control that allows us to disentangle the effect of private trade voyages from legitimate voyages with respect to network integration, density, and size. Here, we assess the robustness of these results by comparing the structure of the trade network for each period with private traders removed to the structure of 100 simulated networks, for each period, controlling for size. Recall that when private traders are removed, only legitimate voyages remain, thus removing private trade voyages from period $T$ leaves us with $N$ legitimate voyages. For each period $T$, we generate 100 new port-to-port networks of size $N$ composed by removing a random draw of legitimate voyages. The resulting network contains private trade and legitimate voyages. 


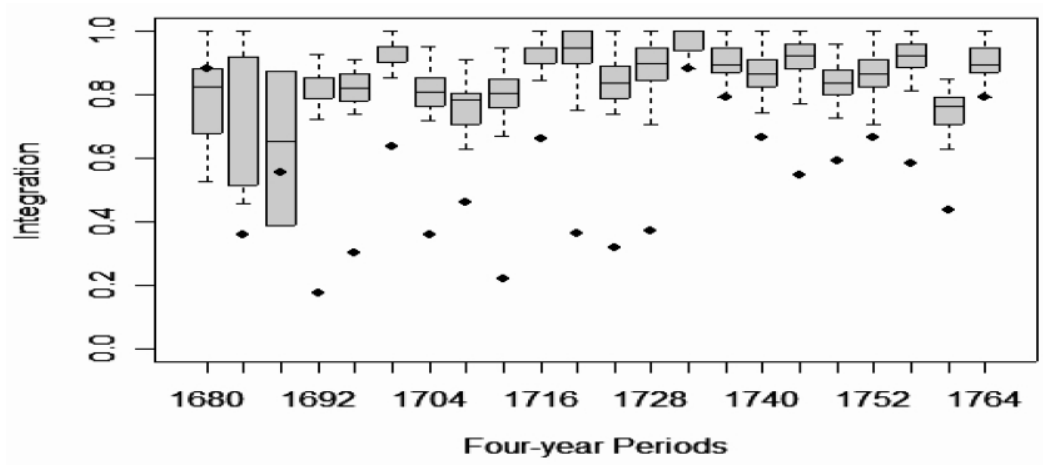

FIG. 7.-Simulations of data presented in fig. 5

We measure the integration, density, size, and bicomponent size of each induced network for each period. This yields a distribution of observations for network integration over each period for the control set, that is, the 2,200 networks composed of both legitimate and private traders. Figure 7 returns these observations. The box plots report the quartiles of the observed integration level taken on the simulated trade networks. For comparison, darkened circles indicate the observations taken on the network with private trade removed.

The results from figure 7 closely replicate those reported in figure 5 and therefore provide additional confirmation of the main finding. Removing private traders has a significant effect on network integration: in each case, the legitimate trade networks are significantly less integrated than the networks where private traders remain.

Figure 8 is designed to provide additional confirmation for the results presented in figure 6 . In figure 6 we report the relative impact of private trading on graph density, number of ports in the trading network, and the size of the largest bicomponent. Recall that the results from figure 6 show that removing private traders reduces density, network size and bicomponent size. Because we now have a distribution of observations, we do not convert the measures into a ratio as in figure 6. Instead, figure 8 reports the distribution of observations generated from the 2,200 simulated networks.

As a guide to figure 8, first consider the percentage of density accounted for by the presence of private traders. In the top view, we calculate the density of each of the 100 simulated networks for each period, subtract these values from the density of the total graph, and divide by total density. This provides us with a measure of the percentage of the total graph density accounted for by legitimate trade voyages. As before, the box plots 
American Journal of Sociology

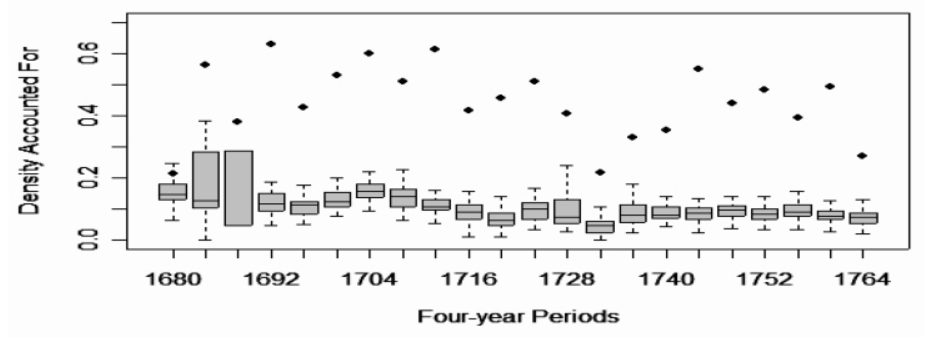

Panel B.-Network size

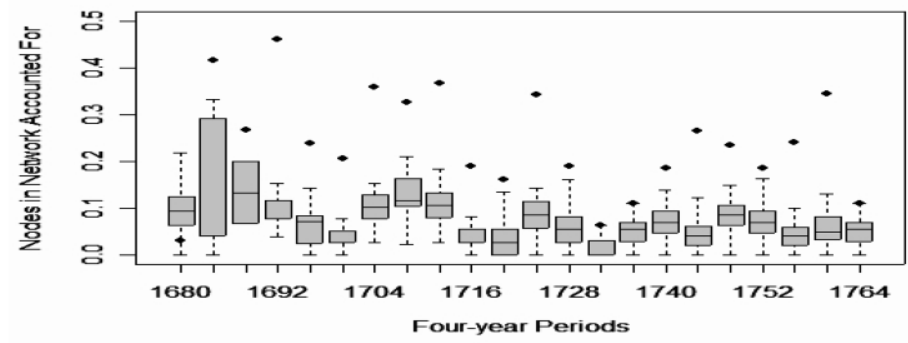

Panel C.-Size of maximum bicomponent

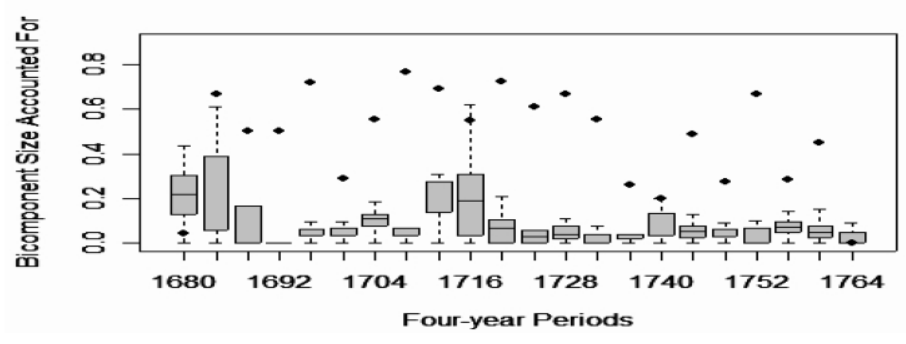

FIG. 8.-Simulations of data presented in fig. 6

represent the distribution of these observations. Again, the circles represent the percentage of the density accounted for by private trade voyages.

In the middle and bottom views of figure 8, we consider network size and the size of the largest bicomponent, respectively. Network size captures the number of ports embedded in the EIC orbit. As noted earlier, larger bicomponents (necessarily composed of redundant ties) strengthen resistance to local control efforts by reducing information asymmetries (Watts 2003). The visualizations in "network size" and "size of maximum bicomponent" confirm that private traders produced larger and more cohesive trade networks. In sum, the results from the simulation confirm 
the finding of the "propensity-matching" approach taken earlierspecifically, they show that the private traders were the binding force creating an integrated market arena in the period between 1680 and 1764 .

\section{DISCUSSION}

In 1738, Henry Kent set off on his first voyage with the EIC - as second mate on the Somerset, destined for Benkulen. Eight years later, in 1746, now captain of the Dragon, en route to China, Kent sailed through the Indonesian Archipelago and landed twice at Tamborneo, a port presumably on or near Borneo never previously encountered by any of the other 4,572 EIC voyages to the East. After this trip, Kent sailed twice to India, with stops in Madras, Calcutta, Culpee, and Benkulen. On these voyages Kent cycled between ports, but never missed a sailing season, returning to England roughly 26 months after departure. By 1752, Kent had sailed through-on different voyages - the entire East.

On his last voyage as captain of the Dragon, Kent left Downs on November 16, 1752, destined for Bengal. He made good time, arriving at the Cape in early February. By March 24, the Dragon sailed into St. Augustine's Bay. Rather than proceeding directly to Madras, Kent went up the coast of Madagascar to Morandava. From April to July, Kent stayed at Morandava, where among other things, he helped establish a factory, exchanged guns, ammunition, and alcohol for meat, water, and slaves; exchanged brandy for a young female slave with the king and queen of Madagascar who had traveled to meet him with their retinue, built slave quarters on his ship, brought on board 74 slaves, dealt with mutinous crew members-three of whom were caught deserting in the ships' longboat-crushed a small slave revolt, and met up with a boat on the EIC register (the Swallow, leaving Downs within days of the Dragon, captained by John Bell, also taking his last trip, for which no existing voyage data are available in EIC records) carrying 71 slaves picked up elsewhere, and took them on board in exchange for items not recorded. Leaving Morandava, Kent made a brief stop at the Morungary River (alternatively, Massalege, now possibly Mahavavy), before setting sail with slaves on board to Madras. Once in Madras, Kent traveled to Calcutta, Culpee, and returned to Madras, completing a cycle, before sailing for Benkulen, and cycling back to Madagascar. Along the way, he missed his sailing season, forcing him to stay in the East an extra year, and thereby incurring additional costs to the EIC. What Kent did with the slaves we do not know.

Over the course of his career, Kent led legitimate and illegitimate voyages. Like other private traders, Kent discovered, and twice returned, to 
a new port, and thereby opened up potential new markets for the EIC. On the voyage described above, Kent engaged in the slave trade, exchanging arms for slaves, and collecting slaves picked up and transported to Madagascar - a haven for pirates-by an EIC vessel (the Swallow) for which no voyage data are available. He did this at a time when the EIC was not engaged officially in the slave trade. The circuits he took wove together the Bengal trading region with the Indonesian archipelago and the vibrant trading world of the East Coast of Africa. Only rarely can one see from our records into the world of the private traders as clearly as for Kent, but the trace of their activity is visible-long stays in the East and cycles between ports. To see this, one has to construct trade networks amenable to structural analysis. The paths of the ships constitute the transportation and communication infrastructure of firm operations. The records of the voyages provide a material trace of the system of exchange involving the English company merchants. Here, we use these paths to induce an image of the company trade over time thereby allowing us to disentangle the legitimate company trade from the illegitimate private trade pursued by company employees.

In 1776, Adam Smith argued that the motor for developing trade across separate societies resided entirely in the local interaction of individual participants. In the EIC context, this line of argument suggested that the private traders-those operating across multiple market arenas-provided the impetus for successful trade, weaving together exotic locales into a global market spanning the Eastern seas. In this version of the story, the monopolistic EIC rode the backs of these entrepreneurial individuals, reaping undeserved profit from the market-making activities of their employees. Following Smith, a free market would have been better; the monopoly form only fettering the pure expression of the English entrepreneurial spirit.

The evidence presented in this article suggests a more complex process. First, the private traders were engaged in malfeasance. Second, the opposition between free-market entrepreneurs and monopoly organization neglects the fact that market making requires an institutional foundation. Private traders did not triumph alone. The private traders needed the EIC infrastructure as foundation, just as the EIC needed private traders for expansion and integration. EIC employment provided captains with distinct competitive advantages through access to greater resources-big ships, money, captive crews, factories, protection from duties, and security on the seas. These advantages made it possible for private traders to get action and make money.

At the same time, the EIC benefited from the distribution of the risk involved in expanding markets in the East. In 1680, confronted with clear evidence that English interests were falling behind those of the Dutch, 
the EIC pulled out of their direct involvement in the country trade. Ironically, this decision enabled the EIC to consolidate and integrate Eastern markets, expand their reach into the East, and heighten the internal transmission of information on prices, goods, and market practices. When the EIC pulled out of the country trade they did not envision that within 80 years they would dominate the East. But that is what happened. Expansion and integration in the east was the unforeseen byproduct of EIC strategic decisions designed to reduce their engagement in intra-Asian trade. Private traders wove local interactions into a global institution (the EIC) creating the dense structures we associate with globalizing processes on the back of the existing trade infrastructure-the goods, men, and information who traveled on the sanctioned arcs linking ports.

One of the lessons of network theory has been that social relations and structure matter even where they may be least expected. That is always a fun finding for sociologists. Here we observe something more unusual; social networks also matter where most expected, in unregulated, uncertain situations crossing cultural, social, and political boundaries. We show that for a limited period of time there emerged a unique opportunity for self-interested actors to act; that their actions cumulated into a network structure that transcended them, and ultimately created the context for their own demise. That this context was also the context for the emergence of modern capitalist markets is fitting, for it suggests that the global capitalist trade networks now so familiar to us were to some significant extent the product of individual malfeasance.

\section{REFERENCES}

$\rightarrow$ Adams, Julia. 1994. "Trading States, Trading Places: The Role of Patrimonialism in Early Modern Dutch Development." Comparative Studies in Society and History 36:319-55.

$\rightarrow$ 1996. "Principals and Agents, Colonialists and Company Men: The Decay of Colonial Control in the Dutch East Indies.” American Sociological Review 61:12-28.

$\rightarrow$ Anderson, Gary M., Robert E. McCormick, and Robert D. Tollison. 1983. "The Economic Organization of the English East India Company." Journal of Economic Behavior and Organization 4:221-38.

Arasaratnam, Sinnappah. 1995. Maritime trade, society and European influence in South Asia, 1600-1800. Brookfield, Vt.: Variorum.

Barber, William J. 1975. British Economic Thought and India, 1600-1858: A Study in the History of Development Economics. Oxford: Clarendon Press.

Barendse, R. J. 1998. The Arabian Seas, 1640-1700. Leiden: Leiden University.

Barlow, Edward. 1934. Barlow's journal of his life at sea in king's ships, East $\mathcal{G}$ West Indiamen $\mathcal{E}$ other merchantmen from 1659 to 1703. Transcribed by Basil Lubbock. London: Hurst \& Blackett.

Basset, D. K. 1960. The Trade of the English East India Company in the Far East, 1623-1684. London: Royal Asiatic Society.

$\rightarrow$ Bearman, Peter S. 1991. "Desertion as Localism: Army Unit Solidarity and Group Norms in the U.S. Civil War." Social Forces 70:321-424. 
American Journal of Sociology

$\rightarrow$ Boorman, Scott A., and Paul R. Levitt. 1973. "A Frequency-Dependent Natural Selection Model for the Evolution of Social Cooperation Networks." Proceedings of the National Academy of Sciences 70:187-9.

Borsa, Giorgio. 1990a. "Recent Trends in Indian Ocean Historiography, 1500-1800." in . New Delhi: Manohar Publications.

1990b. Trade and Politics in the Indian Ocean: Historical and Contemporary Perspectives. New Delhi: Manohar Publications.

Braudel, Fernand. 1972. The Mediterranean and the Mediterranean World in the Age of Philip II. New York: Harper \& Row.

1974. Capitalism and Material Life, 1400-1800. New York: Harper \& Row. 1982. The Wheels of Commerce. New York: Harper \& Row.

Bruijn, J. R., and F. S. Gaastra. 1993. Ships, Sailors and Spices: East India Companies and Their Shipping in the 16th, 17th and 18th Centuries. Amsterdam: NEHA.

Burke, Edmund. 1969. Edmund Burke on Indian Economy, edited by Sunil Kumar Sen. Calcutta: Progressive Publishers.

$\rightarrow$ Burt, Ronald S. 2004. "Structural Holes and Good Ideas." American Journal of Sociology 110:349-99.

$\rightarrow$ Carlos, Ann M. 1992. "Principal-Agent Problems in Early Trading Companies: A Tale of Two Firms." American Economic Review 82:140-45.

$\rightarrow$ Carlos, Ann M., and Stephen Nicholas. 1996. "Theory and History: SeventeenthCentury Joint-Stock Chartered Trading Companies." Journal of Economic History 56:916-24.

Carruthers, Bruce G. 1996. City of Capital: Politics and Markets in the English Financial Revolution. Princeton, N.J.: Princeton University Press.

Chaudhuri, K. N. 1965. The English East India Company: The Study of an Early Joint-Stock Company, 1600-1640. New York,: Reprints of Economic Classics.

- 1978. The Trading World of Asia and the English East India Company, 1660-1760. New York: Cambridge University Press.

. 1993. "The English East India Company's Shipping (c. 1660-1760)." Pp. 49-80 in Ships, Sailors and Spice: East India Companies and Their Shipping in the 16th, 17 th and 18th Centuries, edited by J. R. Bruijn and F. S. Gaastra. Amsterdam: NEHA.

Cotton, Evan. 1949. East Indiamen: The East India Company's Maritime Service. London: Batchworth Press.

Curtin, Philip D. 1994. Cross-Cultural Trade in World History. Cambridge: Cambridge University Press.

Das Gupta, Ashin, and M. N. Pearson. 1999. India and the Indian Ocean, 1500-1800. Oxford: Oxford University Press.

Dodwell, Henry. 1920. Dupleix and Clive: The Beginning of Empire. London: Methuen. Farrington, Anthony. 1999a. A Biographical Index of East India Company Maritime Service Officers, 1600-1834. London: British Library.

.1999b. Catalogue of East India Company Ships'Journals and Logs, 1600-1834. London: British Library.

$\rightarrow$ Finke, Roger, and Rodney Stark. 1988. "Religious Economies and Sacred Canopies: Religious Mobilization in American Cities, 1906." American Sociological Review 53: 41-49.

Fitzgerald, Keane. 1777. A Letter to the Directors of the East India Company. London: T. Payne \& Son.

Furber, Holden. 1948. John Company at Work: A Study of European Expansion in India in the Late Eighteenth Century. Cambridge, Mass.: Harvard University Press. 1976. Rival Empires of Trade in the Orient, 1600-1800. Minneapolis: University of Minnesota Press.

$\rightarrow$ Granovetter, Mark. 1985. "Economic Action and Social Structure: The Problem of Embeddedness." American Journal of Sociology 91:481-510. 
Global Trade

$\rightarrow$ Greif, Avner. 1989. "Reputation and Coalitions in Medieval Trade: Evidence on the Maghribi Traders." Journal of Economic History 49:857-82.

$\rightarrow \longrightarrow$. 1994. "Cultural Beliefs and the Organization of Society: A Historical and Theoretical Reflection on Collectivist and Individualist Societies." Journal of Political Economy 102:912-50.

$\rightarrow$ Grofman, Bernard, and Janet Landa. 1983. "The Development of Trading Networks Among Spatially Separated Traders as a Process of Proto-Coalition Formation: The Kula Trade." Social Networks 5:347-65.

Hage, Per, and Frank Harary. 1991. Exchange in Oceania: A Graph Theoretic Analysis. Oxford: Clarendon Press.

$\rightarrow$ Jones, S. R. H., and Simon P. Ville. 1996a. "Efficient Transactors or Rent-Seeking Monopolists? The Rationale for Early Chartered Trading Companies." Journal of Economic History 56:898-915.

$\rightarrow$. 1996b. "Theory and Evidence: Understanding Chartered Trading Companies." Journal of Economic History 56:925-26.

Keay, John. 1991. The Honourable Company: A History of the English East India Company. London: Harper Collins.

$\rightarrow$ Kiser, Edgar. 1994. "Markets and Hierarchies in Early Modern Tax Systems: A Principal-Agent Analysis." Politics and Society 22:284-315.

$\rightarrow$ Kiser, Edgar, and Xiaoxi Tong. 1992. "Determinants of the Amount and Type of Corruption in State Fiscal Bureaucracies: An Analysis of Late Imperial China." Comparative Political Studies 25:300-331.

Kling, Blair B., M. N. Pearson, and Holden Furber. 1979. The Age of Partnership: Europeans in Asia before Dominion. Honolulu: University Press of Hawaii.

Lawson, Philip. 1993. The East India Company: A History. New York: Longman.

Lombard, Denys. 1981. "Questions on the Contact between European Companies and Asian Societies." Pp. vi, 276 in Companies and Trade: Essays on Overseas Trading Companies during the Ancien Régime, edited by P. H. Boulle, Léonard Blussé, and F. S. Gaastra. Leiden: Leiden University Press.

$\rightarrow$ Lovejoy, Paul E., and David Richardson. 1999. "Trust, Pawnship, and Atlantic History: The Institutional Foundations of the Old Calabar Slave Trade." American Historical Review 104:333-55.

Marshall, P. J. 1976. East Indian Fortunes: The British in Bengal in the Eighteenth Century. Oxford: Clarendon Press.

. 1993. Trade and Conquest: Studies on the Rise of British Dominance in India. Brookfield, Vt.: Variorum.

Marx, Karl. 1969. Karl Marx on Colonialism and Modernization: His Despatches sic and Other Writings on China, India, Mexico, the Middle East and North Africa, edited by Shlomo Avineri. Garden City, N.Y.: Doubleday.

Menard, R. 1991. "Transport Costs and Long-Range Trade, 1300-1800: Was There a European 'Transport Revoluion' in the Early Modern Era?” in Political Economy of Merchant Empires, edited by J. D. Tracy. Cambridge: Cambridge University Press.

$\rightarrow$ Moody, James. 2004. "The Structure of a Social Science Collaboration Network: Disciplinary Cohesion from 1963 to 1999." American Sociological Review 69:213-38.

$\rightarrow$ Moody, James, and Douglas R. White. 2003. "Social Cohesion and Embeddedness: A hierarchical conception of Social Groups.” American Sociological Review 68:103-27.

North, Douglass Cecil. 1990. Institutions, Institutional Change, and Economic Performance. New York: Cambridge University Press.

$\rightarrow$ Perrow, Charles. 1986. "Economic Theories of Organization." Theory and Society 15: $11-45$.

Piore, Michael J., and Charles F. Sabel. 1984. The Second Industrial Divide: Possibilities for Prosperity. New York: Basic Books.

Prakash, Om. 1994. Precious Metals and Commerce: The Dutch East India Company in the Indian Ocean Trade. Brookfield, Vt.: Variorum. 
American Journal of Sociology

1997. European Commercial Expansion in Early Modern Asia. Brookfield, Vt.: Variorum.

Roberts, P. E. 1938. History of British India under the Company and the Crown. Oxford: Clarendon press.

Savage, Mike, Katherine Stovel, and Peter Bearman. 2001. "Class Formation and Localism in an Emerging Bureaucracy: Britsh Bank Workers, 1880-1960." International Journal of Urban and Regional Research 25:284-300.

Saxe, Elizabeth Lee. 1979. "Fortune's Tangled Web: Trading Networks of English Entrepreneurs in Eastern India, 1657-1717." Pp. 344 in History. New Haven, Conn.: Yale University.

Selznick, Philip. 1949. TVA and the Grass Roots: A Study in the Sociology of Formal Organization. Berkeley: University of California Press.

$\rightarrow$ Shleifer, Andrei, and Robert W. Vishny. 1993. "Corruption." Quarterly Journal of Economics 108:599-617.

Smith, Adam. (1776) 1999. The Wealth of Nations. New York: Penguin.

$\rightarrow$ Steensgaard, Niels. 1965. "Freight Costs in the English East India Trade, 1601-1657." Scandinavian Economic History Review 13:143-62.

. 1974. The Asian Trade Revolution of the Seventeenth Century: The East India Companies and the Decline of the Caravan Trade. Chicago: University of Chicago Press.

- 1981. "The Companies as a Specific Institution in the History of European Expansion." Pp. vi, 276 in Companies and Trade: Essays on Overseas Trading Companies during the Ancien Régime, edited by P. H. Boulle, Léonard Blussé, and F. S. Gaastra. Leiden: Leiden University Press.

Stone, R. A., D. S. Obrosky, D. E. Singer, W. N. Kapoor, and M. J. Fine. 1995. "Propensity Score Adjustment for Pretreatment Differences between Hospitalized and Ambulatory Patients with Community-Acquired Pneumonia." Medical Care 33: AS56-AS66.

Toussaint, Auguste. 1966. History of the Indian Ocean. Chicago: University of Chicago Press.

Van Dooselaere, Quentin. 2004. "From Feudal to Modern: Social Dynamics and Commercial Agreements in Medieval Genoa." Manuscript. Columbia University, Department of Sociology.

Watson, Ian Bruce. 1980. Foundation for Empire: English Private Trade in India, 1659-1760. New Delhi: Vikas.

Watts, Duncan J. 2003. Six Degrees: The Science of a Connected Age. New York: Norton.

$\rightarrow$ Weick, Karl E. 1976. "Educational Organizations as Loosely Coupled Systems." Administrative Science Quarterly 21:1-19.

$\rightarrow$ White, Douglas R., and Frank Harary. 2001. "The Cohesiveness of Blocks in Social Networks: Node Connectivity and Conditional Density.” Sociological Methodology 31:305-359.

$\rightarrow$ White, Douglas R., Walter W. Powell, Jason Owen-Smith, and James Moody. 2004 "Networks, Fields and Organizations: Micro-dynamics, Scale and Cohesive Embeddings." Computational and Mathematical Organization Theory 10 (1):95-117.

White, Harrison C. 1985 "Agency as Control." Pp. 187-212 in Principals and Agents: The Structure of Business, edited by John W. Pratt and Richard Zeckhauser. Boston, Mass: Harvard Business School.

Wilbur, Marguerite Eyer. 1945. The East India Company and the British Empire in the Far East. Stanford, Calif.: Stanford University Press.

Williamson, James Alexander. 1953. A Short History of British Expansion. London: Macmillan. 